\title{
Development of Entomology Handout Based on Natural Resources from Tropical Rain Forest
}

\author{
Sonja V.T. Lumowa \\ Biology Education Program \\ Faculty of Teacher Training and Education, \\ Mulawarman University \\ Samarinda, Indonesia \\ verasonja@yahoo.com
}

\author{
Zenia L. Kurniawati \\ Biology Education Program \\ Faculty of Teacher Training and Education, \\ Mulawarman University \\ Samarinda, Indonesia \\ zeniakurniawati2211@gmail.com
}

\begin{abstract}
Lecturers and students of the Biology Education sProgram of Teachers Training and Education Faculty of Mulawarman University have conducted a lot of research in field of entomology including use of natural resources from tropical rain forest as organic pesticides. Unfortunately, they have not been widely used as a source of learning sources in teaching and learning of entomology subjects. The purpose of this study was to develop an entomology handout based on research on the natural resources from tropical rain forest. This research is a research development using ADDIE model. This research conducted analyzing, designing and developing of the entomology handout. The handout was validated by media and content experts. The results showed that the handout was made based on student needs on the entomology courses, the validity of media was very valid and the validity of the content was quite valid. It can be concluded that the entomology handout was feasible used in teaching and learning.
\end{abstract}

\section{Keywords: handout, entomology, tropical rain forest}

\section{INTRODUCTION}

At present, all aspects of life, including education, are digitalized and dependent on technology. Changes in perspective in education have implications for learning activities and its supporting factors. One of them is learning resources. At high school and college, lecturers are not only learning resource, but rather as mediators and facilitators [1]. Learning resource in digital era vary greatly, for example the environment, drawings, sketches, diagrams, films, written teaching materials such as newspaper clippings and scientific articles [2,3], as well as various sources from digital technology media [4].

Research articles are one of the contextual learning resources that support the implementation of contextual learning. Contextual learning can motivate students to make connections between knowledge and its applications to their lives as family members, citizens, and workers and engage in the hard work that learning requires [5]. Another advantages are that it can help students to construct their knowledge, facilitate students to interact with the environment one of which is a social environment, and help students to be able to overcome everyday problems [6]. Lecturers and students of the biology education study program of the Faculty of Teachers Training and Education Mulawarman University have produced a lot of research in the field of entomology, for example about the use of natural resources in the tropical rain forest areas for organic pesticides. Some of the research results have been published, but not widely used as a source of learning materials in class.
Based on authors' observation that was conducted before this study, students used books as learning resources in entomology courses. Most of them also used articles from internet that unknown theirs truth and novelty. We also that, most of sources data in papers prepared by students from the internet and the data were from approximately 2 research articles. During discussion in learning process, students were not using data from research articles, especially research from local wisdom. At present, learning resources developed based on lecturers and students research Biology Education Program of Mulawarman University that support entomology learning has not been found. Developments of contextualbased learning resources from research results of lecturers and students of biology education program of teacher training and education faculty, as well as other faculties at Mulawarman University, on the entomology courses were needed. Through the development the learning resources, students are expected to know relationship between knowledge and its application in life, so they can appreciate local wisdom around them.

Handouts are written materials prepared by a teacher to enrich students' knowledge [7]. Handouts generally contain some literature that relevance to the subject taught. Trough handout, students are easier to master, understand and remember the concepts learned [8]. Handouts can be used as alternative teaching materials in the learning process and give a good influence on student learning outcomes $[9,10,11]$. Handout is arranged with steps such as analyzing curriculum, determining titles, determining achievement competencies, gathering references, writing the handout, rereading and asking friends to read the handout, evaluating the handout and following by revision.

Based on the reason above this study was conducted to analyze, design and develop a handout on entomology subject based on research results of lectures and students of biology education program of Teacher Training and Education Faculty and other related Faculties at Mulawarman University.

\section{METHOD}

This study is categorized as research and development and was conducted at Biology Education Program of Faculty of Teacher Training and Education of Mulawarman University, Samarinda, East Kalimantan Province, Indonesia, in academic year 2018/2019. ADDIE (analysis, design, development, implementation, and evaluation) model was used in this study. This study was conducted in 3 phases; the analysis, the design and the development phases. In the 
analysis phase, an analysis of student characteristics, analysis of student learning resources, understanding of student concepts about entomology courses through grades, and analysis of learning outcomes were carried out. In the design phase, design of the teaching handout including the design of cover, contents, and reference sources were designed. In the development phase, the handout was developed and validated.

The eentomology handouts were validated by content and media experts. The data obtained were quantitative data in the form of assessment scores from the questionnaire and qualitative data in the form of comments and suggestions from validator. Data collection instruments in the form of a validation questionnaire. Validation data were analyzed using percentage techniques. The percentage was calculated using formula (1).

$$
\mathrm{P}=\left(\mathrm{x} / \mathrm{x}_{\mathrm{i}}\right) \cdot 100 \%
$$

where $\mathrm{P}$ is percentage, $\mathrm{x}$ is respondent's answer in one item statement, and $\mathrm{x}_{\mathrm{i}}$ is maximum respondent's answer in one statement.

The scale used in the questionnaire was 5 levels, scale 5 as the highest scale and 1 as the lowest scale. Then the scale was grouped into 4 groups ranging in percentage values as shown in Table 1 [12].

\section{RESULTS AND DISCUSSION}

The results of the analysis student needs show that the students are digital native young generation. Students often use digital media technology in learning and finding learning resources. While, they rarely use text book in library to find the learning resources. The analysis of learning resources showed that number of the learning resources from lecturers and research students at Mulawarman University is limited. Thus, additional supplementary teaching materials were needed to help students learn contextual materials, by developing teaching materials in the form of handouts in entomology courses based on natural resources of tropical rain forests in East Kalimantan.

At the design phase, an entomology handout has an arrangement handout design that includes learning objectives and materials. The handout is designed to contain material about 1) pests, 2) biological control of pests, 3) organic pesticides, 4) organic pesticide plants in East Kalimantan tropical rainforest, 5) How to manufacture and apply organic pesticides. Potential plants as organic pesticides discussed in the handout included babandotan plants, kepok banana peels, breadfruit flowers, pineapple skin, saliara leaves, gamal leaves, avanese chili, red ginger, and kirinyu leaves.

TABLE I. TABle 1 Percentage Analysis VAlidation CRiteria

\begin{tabular}{|c|c|l|}
\hline No. & Validity & \multicolumn{1}{|c|}{ Category } \\
\hline 1. & $85 \leq \mathrm{P} \leq 10$ & $\begin{array}{l}\text { Very valid, or feasible to use without } \\
\text { revision. }\end{array}$ \\
\hline 2. & $70 \leq \mathrm{P}<85$ & $\begin{array}{l}\text { Quite valid, or feasible to use but it needs a } \\
\text { small revision. }\end{array}$ \\
\hline 3. & $50 \leq \mathrm{P}<70$ & $\begin{array}{l}\text { Less valid, recommended not used because it } \\
\text { needs a major revision. }\end{array}$ \\
\hline 4. & $0<\mathrm{P}<50$ & Invalid, or may not be used. \\
\hline
\end{tabular}

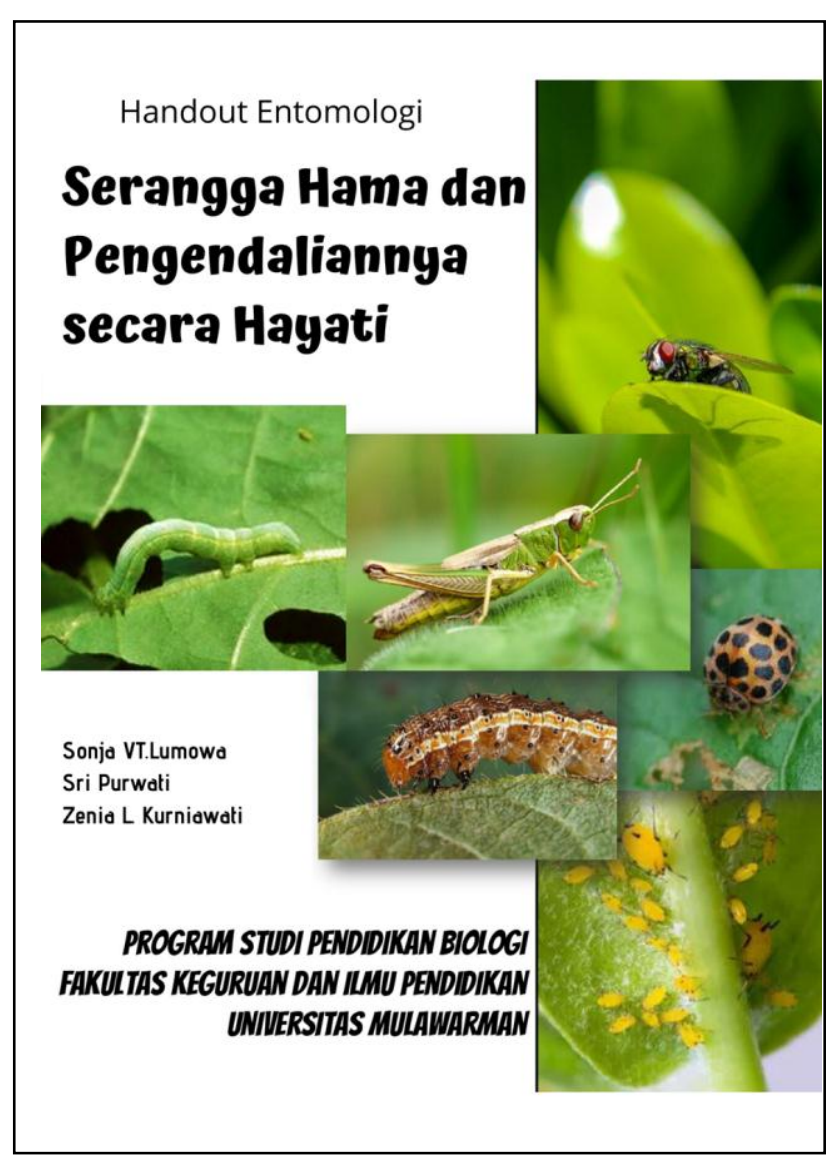

Fig. 1. Cover of the entomology handout

At the development phase, all handout elements are made, including covers, foreword, table of contents, handout material and bibliography. The cover handout is in Fig. 1.

After the handout has been prepared, validation by the content and the media experts was conducted. Media validation indicators include the suitability of learning outcomes with the material on the handout, the feasibility of using handouts for students, the accuracy of graphics, figures and diagrams, as well as the ease of use of the handouts. Content validity test indicators include the suitability of learning outcomes with the material on the handout, the accuracy and correctness of the contents presented in the handout, the accuracy of the graphs, pictures and diagrams and the accuracy of the use of handouts by students.

Results of the validation of the handouts by media and content experts are presented in Fig. 2 and Fig. 3. According to the Fig. 2 and Fig. 3, it is clear that on the indicators of the suitability of learning outcome (called Sub-CPMK), in the category of quite valid both of initial and revised handout, both of validation results by content and media experts. These result shows that there was no increment validity on this indicators. Based on this indicator, it is indicated that further minor revision is needed on the developed handout. On the other indicators, there is increment validity from the initial to the revised handout, both of validation results by media and content experts. However, a number of indicators indicate that improvements on the handout are still needed, especially on the indicator of appropriateness of images and tables and accuracy of use in the aspect of content (see Fig. $3)$. 


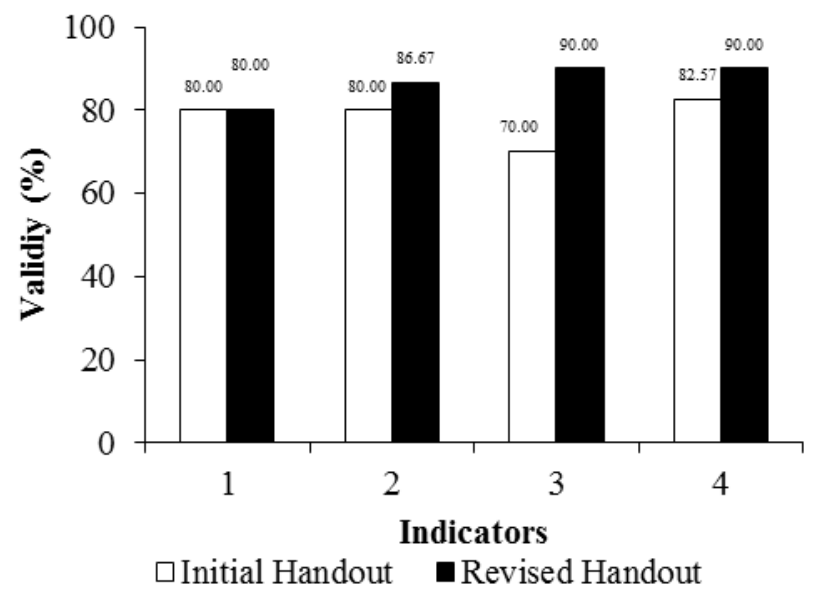

Fig. 2. Results of validity the entomolgy handout by media expert. 1 is sub-CPMK, 2 is eligibility, 3 is appropriateness of images and tables, and 4 is easy of use.

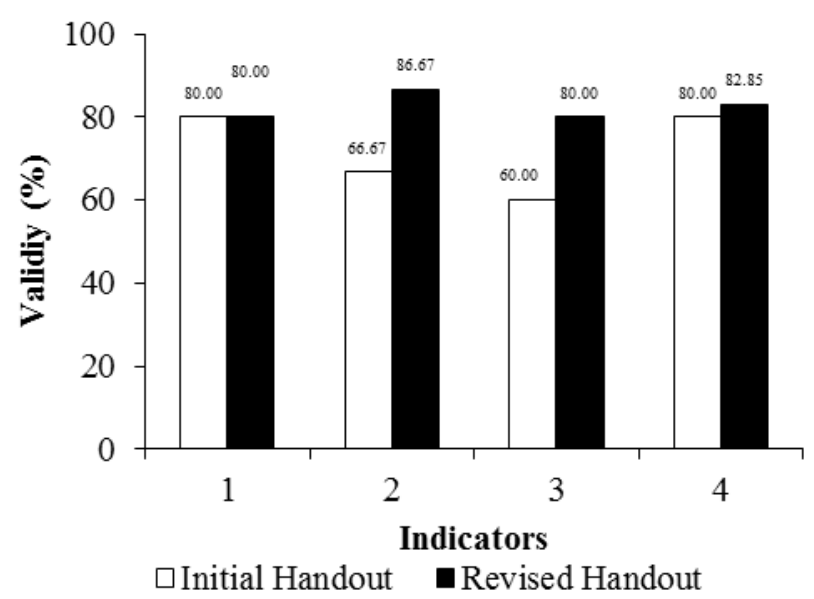

Fig. 3. Results of validity the entomolgy handout by content expert. 1 is sub-CPMK, 2 is suitability and accuracy of the contents, 3 is appropriateness of images and tables, and 4 is accuracy of use.

TABLE II. VALIDITY OF The ETOMOLOGY HANDOUT

\begin{tabular}{|c|c|c|c|c|c|}
\hline \multirow{2}{*}{ No } & \multirow{2}{*}{ Expert } & \multicolumn{2}{|c|}{ Initial Design } & \multicolumn{2}{c|}{ After Revision } \\
\cline { 3 - 6 } & Validity & Category & Validity & Category \\
\hline 1 & $\begin{array}{l}\text { Handout } \\
\text { as Media }\end{array}$ & $78.14 \%$ & $\begin{array}{l}\text { Quite valid, or } \\
\text { feasible to use } \\
\text { but it needs a } \\
\text { small revision. }\end{array}$ & $86.67 \%$ & $\begin{array}{l}\text { Very valid, or } \\
\text { feasible to use } \\
\text { without } \\
\text { revision. }\end{array}$ \\
\hline 2 & $\begin{array}{l}\text { Contents } \\
\text { on } \\
\text { Handout }\end{array}$ & $71.67 \%$ & $\begin{array}{l}\text { Quite valid, or } \\
\text { feasible to use } \\
\text { but it needs a } \\
\text { small revision. }\end{array}$ & $82.00 \%$ & $\begin{array}{l}\text { Quite valid, or } \\
\text { feasible to use } \\
\text { but it needs a } \\
\text { small revision. }\end{array}$ \\
\hline
\end{tabular}

Table 2 shows that the validity of the handout as media was increase from $78.14 \%$ (the initial handout) to $86.57 \%$ (the revised handout). The revised handout was categorized as very valid, feasible to use without further revision. Based on the materials, the validity of the handout was increase from $71.67 \%$ (the initial handout) to $82.00 \%$ (the revised handout). The materials in the revised handout were categorized as quite valid and feasible to use with minor revision. Based on the validity of media and materials above, it is clear that the developed handout was suitable for use in the learning process. Contextual based learning can improve student learning outcomes [13]. Learning using handouts is also expected to make students more active and learning more enjoyable [14]. This handout is expected create active learning where students active and enjoy in learning, and finally improve their learning outcomes.

\section{CONCLUSION}

The entomology handout was developed. The developed handout was very valid as a media and the content of the handout was quite valid. The developed entomology handout was feasible to be used in the entomology course.

\section{REFERENCES}

[1] M. Terpollari. "Teacher's role as mediator and facilitator," European Scientific Journal, vol. 24, 1857, pp. 68-74.

[2] P. Atmodiwirjo, "School ground as environmental learning resources: teachers' and pupils' perspectives on its potentials, uses and accessibility," International Electronic Journal of Environmental Education, vol. 3(2), 2013, pp.101-19.

[3] R. Bušljeta, "Effective use of teaching and learning resources," Czech-Polish Historical and Pedagogical Journal, vol. 5(2), 2013, pp. 55-69.

[4] M.J. Eady and L. Lockyer. "Tools for learning: technology and teaching strategies," Learning to Teach in the Primary School, 2013, p. 71 .

[5] Khaefiatunnisa. "The effectiveness of contextual teaching and learning in improving students' reading skill in procedural text (a quasi-experimental study of the second grade students at one vocational school in Bandung)," Journal of English and Education, vol. 3(1), 2015, pp. 80-95.

[6] I. Satriani, E. E,ilia, and H. Gunawa, "Contextual teaching and learning approach to teaching writing," Indonesian Journal of Applied Linguistics, vol. 2(1), 2012, pp. 10-22.

[7] Ministry of National Education. "guidelines for developing teaching materials". Jakarta: Ministry of National Education, Directorate General of Primary and Secondary Education Management, Directorate of High School Development, 2008.

[8] H. Sanaky, "Learning media: a compulsory handbook for teachers and lecturers," Yogyakarta: Kaukaba Dipantara, 2011.

[9] Y. Parsudi, A. Lukman, and W.D. KArtika "Development of biology learning handout about restoration of mangrove ecosystems based on socioscientific issues in high schools," 2017.

[10] G. Munyoro, "An Evaluation of the effectiveness of handouts in enhancing teaching and learning in higher education." Africa Development and Resources Research Insitute Journal, vol. 5(2), 2014, pp. 1-19.

[11] R. Hera, K. Khiaril, and H. Hasanuddin, "Development of contextualbased embryology learning handouts in animal development lectures to enhance understanding of student concepts at Muhammadiyah University in Banda Aceh," EduBio Tropika Journal, vol. 2(2), 2015, pp. 223-229.

[12] S. Akbar, Learning instruments, Bandung: PT Remaja Rosdakarya. 2013.

[13] H. Qudsyi, H.E. Wijaya, adn N. Widiasmara, Effectiveness of contextual teaching and learning (CTL) to improve students achievement and students' self-efficacy in cognitive psychology course, 2018, pp. 143-46.

[14] R. Ningtyas, T.N.H. Yunianta, and W. Wahyudi "Development of thematic learning handouts for elementary school students class III." Scholaria: Jurnal Pendidikan Dan Kebudayaan, vol. 4(3), 2014, p. 4253. 